\title{
Pre-cooling by hands and feet water immersion reduces heat strain while wearing protective clothing
}

\author{
Ken Tokizawa ${ }^{*}$, Tatsuo Oka ${ }^{1}$, Akinori Yasuda ${ }^{1}$, Tetsuo Tai ${ }^{1}$, Son Suyoung ${ }^{1}$, Jun Wada², Hirofumi Ida ${ }^{2}$ \\ From 15th International Conference on Environmental Ergonomics (ICEE XV) \\ Portsmouth, UK. 28 June - 3 July 2015
}

\section{Introduction}

Pre-cooling (i.e., removal of heat from the body immediately prior to exercise) is a popular strategy for improving exercise performance in hot conditions. Whole body immersion in water is the procedure most commonly used to pre-cool in sports activities. However, the supply of a large volume of water and ice in all occupational settings is not always possible, or practical. In the present study, we examined the effectiveness of hands and feet water immersion and cooling vest as practical precooling method on heat strain while wearing protective clothing.

\section{Methods}

Nine males engaged in $60 \mathrm{~min}$ of walking at a moderate speed $\left(2.5 \mathrm{~km} \cdot \mathrm{h}^{-1}\right)$ in a hot environment $\left(37^{\circ} \mathrm{C}, 50 \%\right.$ rh). Before walking, they immersed hands and feet in mild cold water $\left(18{ }^{\circ} \mathrm{C}\right)$ or temperate water $\left(28{ }^{\circ} \mathrm{C}\right)$ and wore a cool-vest (Phase Change Material: melting temperature $28{ }^{\circ} \mathrm{C}, 1680 \mathrm{~g}, 276 \mathrm{~kJ}$, start from $20{ }^{\circ} \mathrm{C}$ ) for $30 \mathrm{~min}$. The water was wiped off and the vest was taken off, then they wore protective clothing and a full-face gas mask.

\section{Results}

Rectal temperature $\left(\mathrm{T}_{\mathrm{re}}\right)$ at the end of walking was lower in the temperate- and mild cold-water cooling trials than in the control trial (without the pre-cooling) (shown in the figure, $\mathrm{p}<0.05)$. Mean (SD) $\mathrm{T}_{\mathrm{re}}$ during walking increased by $1.1\left(0.3{ }^{\circ} \mathrm{C}\right)$ in the control trial. The precooling in the mild cold-water inhibited the increase $\left(0.8\left(0.2^{\circ} \mathrm{C}\right), \mathrm{p}<0.05\right)$, but that in the temperate-cold

* Correspondence: tokizawa@h.jniosh.go.jp

${ }^{1}$ National Institute of Occupational Safety and Health, Kawasaki, Japan

Full list of author information is available at the end of the article water did not $\left(0.9\left(0.3{ }^{\circ} \mathrm{C}\right)\right)$. In addition, sweat rate, thermal unpleasantness, physical and psychological fatigues were lower in the pre-cooling trials than in the control trial $(\mathrm{p}<0.05)$. In the mild cold-water cooling trial, the changes in heart rate, thermal sensation, and damp sensation were also attenuated $(\mathrm{p}<0.05)$.

\section{Discussion}

We additionally examined that the effect of with or without cooling vest on heat strain in the mild cold-water cooling trial. Because no significant difference was observed, hands and feet water immersion could be mainly effective on alleviating heat strain. The extremities are frequently targeted for cooling [1], as they are usually easy to access and highly vascularized [2]. This study is the first to show the pre-cooling effect of hands and feet on heat strain, whereas previous studies used the cooling procedure during and after exercise [1]. The mitigation effects in cooling at $28^{\circ} \mathrm{C}$ were closer to those in cooling at $18{ }^{\circ} \mathrm{C}$, which may be due to a less powerful peripheral vasoconstrictor response [3].

\section{Conclusion}

Hands and feet water immersion could be an alternative pre-cooling method alleviating heat strain. Although colder water induces more physiological and psychological benefits for heat strain, using tap water (moderate) can also yield lower heat strain for a certain level.

\section{Authors' details \\ ${ }^{1}$ National Institute of Occupational Safety and Health, Kawasaki, Japan. \\ ${ }^{2}$ Tokyo Electric Power Company, Yokohama, Japan.}

Published: 14 September 2015 


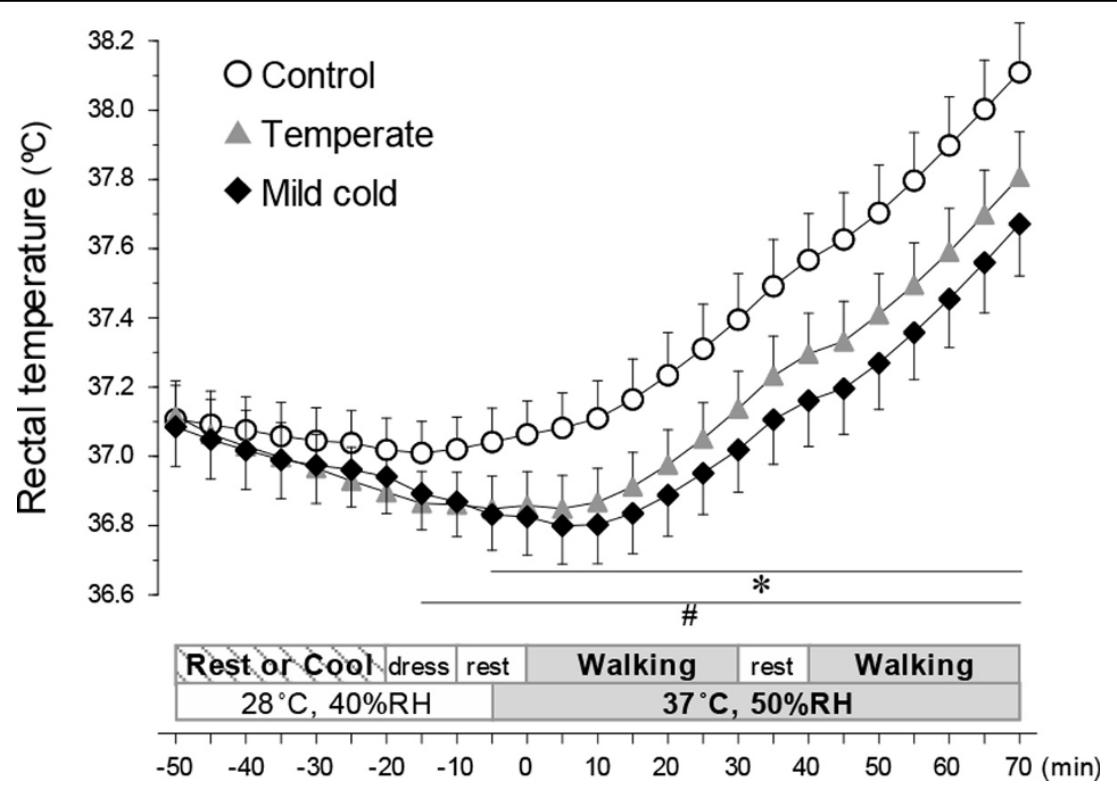

Figure 1 *Different $(p<0.05)$ between the control and mild cold-water cooling trials; \#different $(p<0.05)$ between the control and temperate-water cooling trials.

\section{References}

1. DeGroot $D$, et al: Extremity cooling for heat stress mitigation in military and occupational settings. Journal of Thermal Biology 2013, 38(6):305-10.

2. Taylor NAS, et al: Hands and feet: physiological insulators, radiators and evaporators. European Journal of Applied Physiology 2014, 114(10):2037-60.

3. Taylor NAS, et al: To cool, but not too cool: that is the questionimmersion cooling for hyperthermia. Medicine and Science in Sports and Exercise 2008, 40(11):1962-9.

\section{doi:10.1186/2046-7648-4-S1-A106}

Cite this article as: Tokizawa et al:: Pre-cooling by hands and feet water immersion reduces heat strain while wearing protective clothing.

Extreme Physiology \& Medicine 2015 4(Suppl 1):A106.
Submit your next manuscript to BioMed Central and take full advantage of:

- Convenient online submission

- Thorough peer review

- No space constraints or color figure charges

- Immediate publication on acceptance

- Inclusion in PubMed, CAS, Scopus and Google Scholar

- Research which is freely available for redistribution 